\title{
Glophymed: An index to establish the ecological status for the Water Framework Directive based on phytoplankton in coastal waters
}

\author{
Romero, I.*, Pachés M., Martínez-Guijarro, R., Ferrer, J.
}

Instituto Universitario de Investigación de Ingeniería del Agua y Medio

Ambiente. Universitat Politècnica de València, Camino de Vera s/n, 46022, Valencia, Spain

*IIAMA-UPV Camino de Vera s/n, 46022 Valencia, Spain telf:+34-963877616; fax: +34 963879793

\section{E-mail address: inrogi@dihma.upv.es}

\begin{abstract}
Phytoplankton and its attributes (biomass, abundance, composition, and frequency and intensity of phytoplankton blooms) are essential to establish the ecological status in the Water Frame Directive. The aim of this study is to develop an index "Glophymed" based on all phytoplankton attributes for coastal water bodies according to the directive requirements.

It is also developed an anthropogenic pressure index that takes into account population density, tourism, urbanization, industry, agriculture, fisheries and maritime transport for Comunitat Valenciana (Spain).

Both indexes (Glophymed and human pressure index) based on a multisampling dataset collected monthly during several years, show a significant statistical correlation ( $r 20.75 \alpha<0.01$ ) for typology II-A and ( $r 20.93 \alpha<0.01$ ) for typology III-W. The relation between these indexes provides suitable information about the integrated management plans and protection measures of water resources since the Glophymed index is very sensitive to human pressures.
\end{abstract}

\section{Key Words}

Water Framework Directive, ecological indicators, phytoplankton, coastal waters, Mediterranean Sea, anthropogenic pressure

\section{Introduction}

The European Water Framework Directive (WFD; 2000/60/EC) establishes a framework for the protection of all waters including inland surface waters, transitional waters, coastal waters and groundwaters. This Directive aims at achieving 'good water status' for all waters, by 2015.

The WFD requires Member States (MS) to assess the Ecological Quality Status (EQS) of water bodies. The EQS will be based upon the status of the biological, hydromorphological and physico-chemical quality elements, with the biological elements being especially important. In coastal waters one of the key biological elements is phytoplankton which is also the only planktonic element referred to in the WDF.

Phytoplankton has an important ecological function as primary producer that directly and indirectly fuels the food webs. Moreover, it plays a number of other major roles in many ecosystem processes (Domingues et al. 2008). For that phytoplankton is employed as an indicator of change in nutrient loads and as a key element for assessing eutrophication in marine systems (Garmendia et al. 2012). Therefore phytoplankton and its attributes (biomass, composition, abundance and frequency and intensity of blooms) are fundamental in defining and classifying the ecological status of surface waters according to the WFD. 
Although chlorophyll a has been widely used as an estimator of phytoplankton biomass in the majority of monitoring programs this measure presents obvious difficulties when establishing eutrophic levels (Pachés et al. 2012). In the other hand, phytoplankton composition and abundance provide more reliable information of the rapid and complex responses to fluctuations of environmental conditions (Brogueria et al. 2007).

To achieve the "good water status", the WFD requires MS to assess the ecological quality status of their respective water bodies through a series of steps, including: characterisation of surface waters, establishment of typology; establishment of monitoring programmes; definition of type-specific reference conditions (RC) for biological quality elements (BQE); classification of all surface water bodies using Ecological Quality Ratios (EQR) based on biological quality elements; and, finally, Intercalibration exercise (IC).For that purpose, several Geographic Intercalibration Groups (GIG -groups of MS that share the same water body types in different subregions or ecoregions) were formed to address the distinct categories of superficial waters. In the Mediterranean Sea the working group MedGIG (Mediterranean Geographic Intercalibration Group) is the responsible for the IC process. This, regarding to $\mathrm{BQE}$ phytoplankton, in its first IC phase considered only chlorophyll a as indicator of phytoplankton biomass (European Commission, 2009).

The MS were encouraged to incorporate the other remaining metrics in the $2^{\text {nd }} I C$ phase, however at the end of the phase the MS concluded that the remaining metrics of phytoplankton are not synonymous of environmental quality and therefore they do not add more information than chlorophyll $a$.

In other GIG's some national methods have taken into account not only chlorophyll a as a biomass indicator but elevate cells counts and or frequency of blooms (\%) of any single phytoplankton taxa (European Commission, 2009) leading a more accurate classification of the water bodies.

For that reason the aim of this paper is to establish the ecological status for coastal water based on the whole phytoplankton metric determined by the WFD although at the moment only chlorophyll a is the parameter agreed. It is also a purpose to set out the large body of research carried out in the Comunitat Valenciana (Spain) in the WFD implementation process for coastal water bodies since 2005, that allow an integrated management plan and protection measures of water resources.

\section{Methodology}

\subsection{Surveillance monitoring}

All MS shall establish surveillance monitoring programmes to provide the overall surface water status. Moreover, adhering to the stipulations of the MedGIG for the BQE- phytoplankton, monitoring of the coastal water body in the Comunitat Valenciana was performed monthly since 2005. The stretch coastline of $476 \mathrm{~km}$ was divided into 18 water bodies where 4-6 sampling station were defined for each water bodies (Fig.1).

Water samples are taken from the water column at a $10 \mathrm{~cm}$-depth, and from beyond the wave breakpoint to avoid extracting samples from areas where the effect of wave motion might generate sediment resuspension and, in turn, affect the biochemical quality of the water (Pachés et al. 2012). Sample water for salinity and chlorophyll a analysis was collected in 2-litre plastic bottles, kept refrigerated at $4^{\circ} \mathrm{C}$ and carried to the laboratory (always within the first 12 hours after collected). For phytoplankton samples were stored in glass bottles of $250 \mathrm{~mL}$ and fixed in situ with glutaraldehyde (2\% final concentration) according to Sournia (1978). 


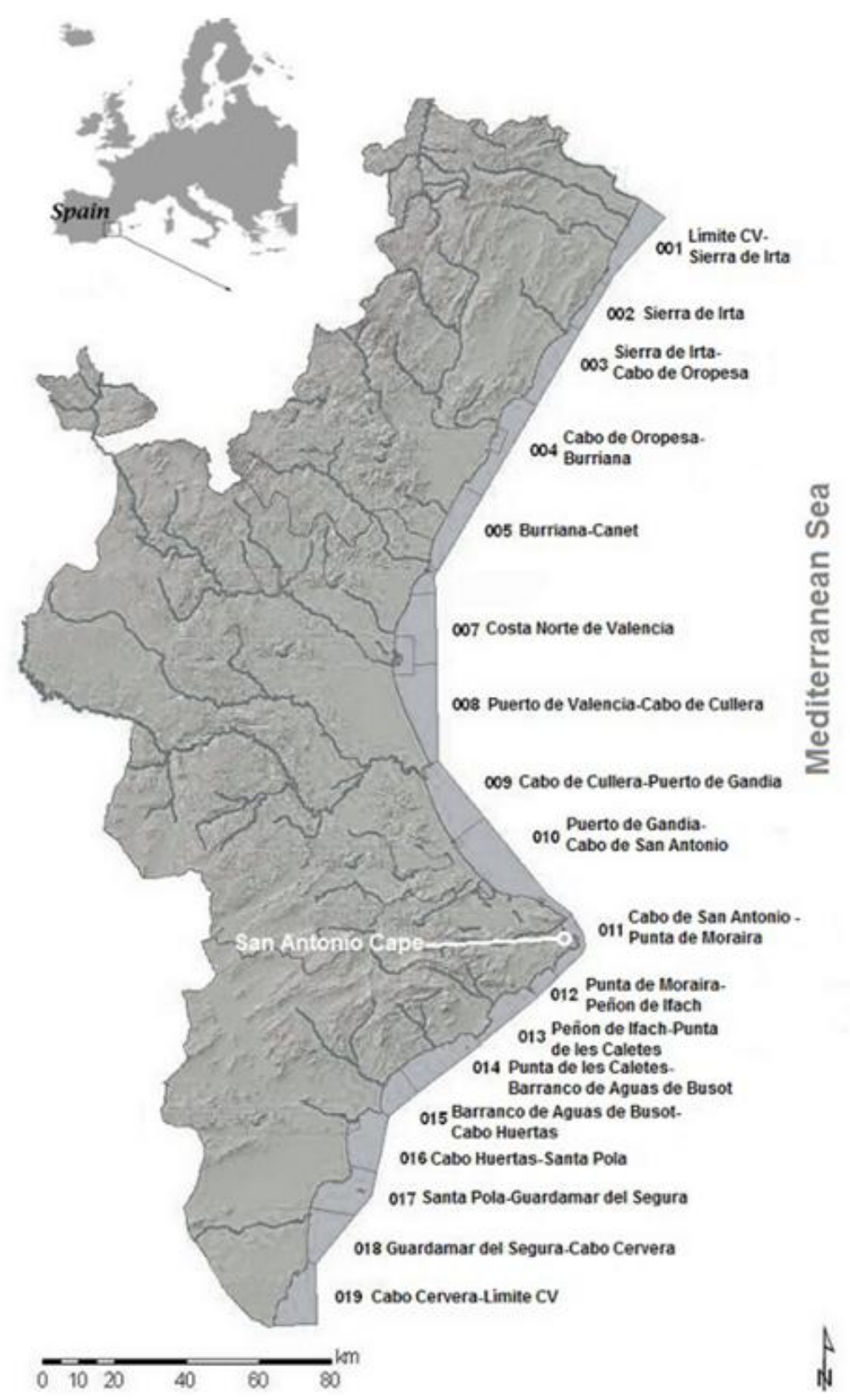

Fig.1. Coastal Water Bodies for Typologies II-A and III-W in the Comunitat Valenciana Region. Typologies described in section 2.2

Once in the laboratory, the samples were divided into several aliquot parts, following the conservation procedures suggested by APHA (2005). The samples were filtered through cellulose acetate membrane filters of $0.45 \mu \mathrm{m}$ (Millipore HAWP) for chlorophyll a analyses. On the determination of chlorophyll a the trichromatic method was used, based on spectrophotometry (APHA, 2005).

Salinity was measured with Portasal Guildline 8410 A, calibrated with the suitable standards (I.A.P.S.O. Standard Seawater, Ocean Scientific International Ltd, K15= $0.99986, S=34.995 \%$ ).

Phytoplankton analyses were carried out by filtering the samples through a $0.2 \mu \mathrm{m}$ membrane filter. Algal counts were made by epifluorescence microscopy (Vargo, 1978) with a Leica DM2500 microscope, using a 100x oil-immersion objective. A minimum of 300 cells were counted and at least 100 cells of the most abundant species or genera were counted with an error below $20 \%$ (Lund et al. 1958). 


\subsection{Typology}

The water body typologies for the Comunitat Valenciana have been established using a landscape approach as required by the WFD. An analysis of the entire region was undertaken, taking into account not only coastal waters, but also littoral coastline influences (Hermosilla, 2009). Geomorphology, littoral transport, dominant winds, rainfall, the area of the fluvial basins, continental inputs and wet zones were taken into account. The outcome of this holistic approach revealed that San Antonio Cape effectively divides the Comunitat Valenciana into two areas: to the north one, Type II-A (Fig.1 water bodies from 001 to 010), with a moderate influence of freshwater inputs, and the south one, Type III-W (Fig.1 water bodies from 011 to 019), without continental influence.

In the area north of the Cape's delimitation, the coastline is regular and almost rectilinear, predominated by sand deposits. Furthermore, in this northern partition the river basins are larger and receive continental inputs from rivers and irrigation channels and its wetlands possess oligohaline waters. In contrast, at the south of the Cape high and low cliffs predominate (BEACHMED, 2003; Serra, 2002); winds are south-easterly (Serra and Medina, 1996); and the river basins are smaller, with predominantly dry riverbeds en route to the sea (Serra, 2002). Moreover, wetlands to the south are generally hypersaline with some brackish water influences (GVA, 2002).

These typologies offer the advantage of stability, as the types do not change substantially over a period of years, despite temporary shifts in rainfall or other climatic circumstances.

Once typologies are established (Type II-A with a moderate influence by freshwater input and III-W without continental influence) further divisions of the coast occur in several water bodies. Typology II-A comprise water bodies from 001 to 010 (Fig.1), and typology III-W from 011 to 019 (Fig.1).

\subsection{Anthropogenic Pressure: LUSIVal index}

The assessment of the anthropogenic pressures on the coastal zone is essential to develop management plans required for compliance of the WFD. In addition the ecological status needs to be linked to anthropogenic pressures.

The pressures on the coastal zone are related mainly to the population density, tourism, urbanization, industry, agriculture, fisheries and maritime transport. Moreover different land uses generate external supplies of nutrients to aquatic ecosystems that stimulate algal growth. Although this is very variable (derived from a wide variety of sources), there is a gradient of nutrient richness from the contributions that range from a minimum in land in its natural state up to urban areas.

However, other factors like coastline morphology should also be taken into account when dealing with pressure. The continental influence is maximized in concave areas of the coast (a lot of land in a little water inflow with low removal times, e.g. bay) and minimized in convex areas (high inflow with more dilution e.g. headland).

Based on these principles, a first anthropogenic pressure index LUSI (Land Uses Simplified Index) was developed by Flo et al. (2011) which is a specific combination of pressures that influences a water body. This index was adapted to the Comunitat Valenciana features yielding a new index named LUSIVal. This index aims to identify all anthropogenic pressures related to phytoplankton impacts on coastal areas, and whose relationship is due to a known mechanism.

The index LUSIVal is obtained as follow:

(Eq 1) LUSIVal = (score urban + score agriculture + score industrial + score typology + others significant pressures $)^{*}$ correction number 
For urban and agricultural (irrigated) pressures, two equations are used:

(Eq 2) Urban score $=3.333^{*} 10$ exp-6 ${ }^{*}$ population number in littoral cities

(Eq 3) Agricultural score $=4.286^{*}$ exp $-5{ }^{*} \mathrm{~m}^{2}$ cultivates in agriculture basin area

For industrial pressures, different categories have been created depending on the percentage of surface used for this activity in a strip of $1.5 \mathrm{~km}$ from the coast. For river/continental pressure, different categories have been created depending on salinity, thus each water body has been assigned to a different category depending on its typology.

\begin{tabular}{|l|l|l|}
\hline Industrial & River (Typology) & Score \\
\hline$<10 \%$ & Type III-W & 0 \\
\hline$>10 \%$ & Type II-A & 1 \\
\hline & Type I & 2 \\
\hline & & 3 \\
\hline
\end{tabular}

Table 1: Score for the industrial and typology pressures for LUSIVal index

For others significant pressures, different aspects have been taken into account. These are: Rivers and channels that due to its high nutrient discharge might significantly affect, Score $=1$; Harbours that significantly affect due to its intensive port activity, Score $=1$ and the influence of adjacent water bodies that significantly affect, Score $=1$.

For each water body all scores are summed. Afterwards, a correction is applied to the sum in order to take into account the degree of confinement that could emphasize or diminish the effect of these pressures on the water body. Depending on the shape of the coastal line the sum is multiplied by a correction number:

\begin{tabular}{|l|l|}
\hline Confinement & Correction number \\
\hline Concave & 1.25 \\
\hline Convex & 0.75 \\
\hline Straight & 1.00 \\
\hline
\end{tabular}

Table 2: Correction number for the confinement for LUSIVal index

\subsection{Establishment of Reference Conditions}

Reference sites have been identified according to the low pressures and impacts that they receive in accordance with Annex $V$ of WFD. For now, thanks to the development pressure index LUSIVal there has been a strong tool to verify these selected zones. A water body was chosen as a reference if it was an undisturbed site or a site with only very minor disturbance derived from the sort of anthropogenic source listed before, which must be associated with lower LUSIVal values in each type.

\subsection{Global Phytoplankton Index}

In the Comunitat Valenciana a first index Phymed (Pachés et al. 2012) including biomass, abundance and composition was developed in order to achieve the WFD requirements. Nevertheless this first index did not consider the intensity and frequency of blooms, for that reason further effort were done to include the whole set of phytoplankton parameters in a global index that enables to establish the ecological status for the BQE of phytoplankton. 
Thus, a global index named Glophymed (Global phytoplankton Mediterranean) including all of these parameters has been developed for Valencia Regions as follows:

(Eq 4) Glophymed $=($ Biomass index + Composition index + Bloom index $) / 3$

Each of the sub-metrics is calculated as independent and all of them are combined into one. For all the sub-metrics developed in $\mathrm{Eq} \mathrm{4,} \mathrm{the} \mathrm{ratio} \mathrm{is} \mathrm{expressed} \mathrm{as} \mathrm{a} \mathrm{numerical}$ value between zero and one, with high ecological status represented by values close to one and bad ecological status by values close to zero (WFD Annex V)

Each of the sub-metrics is explained below.

\section{Biomass index}

The MedGIG in the $1^{\text {st }}$ IC phase established chlorophyll a as a proxy of biomass using the $90^{\text {th }}$ percentile for a five-year period for coastal waters (European Commission, 2009). The value of this biomass metric is represented by the relationship between the value of chlorophyll $a$ in a water body and the value of the reference conditions applicable to the water body.

Moreover the boundaries between "High" and "Good" ecological classes were defined for both typologies (Type II-A and III-W). Thus the biomass index is defined as follows:

(Eq 5) Biomass index $=\left(90^{\text {th }}\right.$ percentile of chl a reference site $) /\left(90^{\text {th }}\right.$ percentile of $\mathrm{chl}$ a water body)

\section{Composition index}

To tackle the study of this parameter a modification of the preliminary index Phymed (Pachés et al. 2012) was done. Only three of the four components of the previous index were taken into account in determining phytoplankton composition. The fourth component is related to total chlorophyll $a$ and since the new Global Phytoplankton index has the biomass parameter already defined it is redundant to keep this fourth component here.

The composition index yielded is as follows:

(Eq 6) Composition index $=[$ index $(E T+c n b /$ picocnb $)+$ index $($ Prym/ Dtm + Cryp $)+$ index $(\%$ Prym) $) / 3$

Parameter 1 (ET+cnb/picocnb): The variable (Total Eukariotic cells + Cyanobacteria)/Picocyanobacteria express the relation between nano and microplankton forms and the picoplankton forms of the community. The later functional group is a good indicator of oligotrophic conditions (Webber et al. 2005) and, moreover it is omnipresent in all ecosystems. Several studies have pointed out that the relative contribution of the smaller phytoplankton classes, in terms of either chlorophyll a or primary production, showed a significant negative correlation with nutrient concentrations, chlorophyll a concentrations and primary production rates (GotsisSkretas et al. 2000). However, a greater proportion of micro phytoplankton is related to higher nutrient concentrations (Puigserver et al. 2002).

Parameter 2 (Prym/Dtm+Cryp): The variable Prymnesiophyceae/(Diatom+Crypto phyceae) represents the relation between a typical oligotrophic group (Prymnesiophyceae) and the groups most adapted to eutrophic environments, such as diatoms and Cryptophyceae (Moncheva et al., 2001).

Parameter 3 (\%Prym): Percentage of Prymnesiophyceae, this phytoplankton group domains the community in oligotrophic marine environment when thermic stratification conditions prevail.

The index is calculated by the $50^{\text {th }}$ percentile of cell density in coastal water date normalized previously applying logarithmic and its values for the reference conditions. 


\section{Bloom index}

As it is pointed out in the WFD frequency and intensity of phytoplankton blooms, are required to be evaluated by MS. For that purpose an index for both, frequency and intensity, was developed for the Comunitat Valenciana coastal waters. Both metrics are calculated as independent and then these are combined into one. The whole bloom index is as follows:

(Eq 7) Bloom index $=($ Intensity index + Frequency index $) / 2$

\section{Intensity index}

(Eq 8$)$ Intensity index $=\left(90^{\text {th }}\right.$ percentile of cell density Reference Condition $) /\left(90^{\text {th }}\right.$ percentile of cell density water body)

Under some environmental condition cell density reach high values, this is known as intensity. Taken into account the values obtained for the reference conditions for both typologies a threshold of cell densities is determined as the 90th of total eukaryotic (ET) cell. The relation between the $90^{\text {th }}$ percentile of cell density in coastal water bodies and those in the reference conditions yields the value of the index.

\section{Frequency index}

(Eq 9) Frequency index $=1$ - $(0.01 * \%$ frequency $)$

Frequency is defined as the number of times that phytoplankton cell density exceeds the threshold (is a sum of occurrences of) established to define a bloom episode. For that purpose, the number of times that each water body cell-density exceeds the threshold is determined (quantified). These numbers of times represent a percentage of the total time sampled during five years. Finally, a value between 0 and 1 is obtained, 0 means that the threshold number is never exceed and 1 means that is always.

Mean values of these two individual indexes provide the value of the bloom parameters.

\section{Results and Discussion}

\subsection{Anthropogenic Pressure: LUSIVal index and Reference conditions}

Once the LUSIVal index is applied the lowest scores of pressure were obtained both, in water body 002 "Sierra de Irta" (1.05) for Type II-A, and in water body 012"Punta de Moraira-Peñón de Ifach" (0.05) for Type III-W. Therefore, these two water bodies were chosen to represent the Reference Conditions for the two typologies.

The water body 002 represents an extensive undeveloped littoral area in the Comunitat Valenciana with low population density and in addition, the sea area around this strip has been declared a marine reserve by the regional government. The water body 012 has also different degrees of legal protection instituted by the regional government that support the environmental quality of the area

\subsection{Pressure and Biological Quality element correlation}

Since changes in environmental status are related to human pressures it is important to verify that the global phytoplankton index responds well to the varying range in pressure. Fig. 2 shows a statistically significant correlation between the global phytoplankton index GLOPHYMED and the anthropogenic pressure index (LUSIVal).

There is a clear gradient of the two metrics, pressure index LUSIVal, and phytoplankton index Glophymed among the coastal water bodies in the Comunitat Valenciana. The lesser anthropogenic pressure received the better Glophymed values achieved. There is one water body in Typology II-A with a Glophymed value higher 
than one but, as it is mentioned in WFD CIS Guidance Document No. 5, for phytoplankton EQR values higher than one are acceptable.

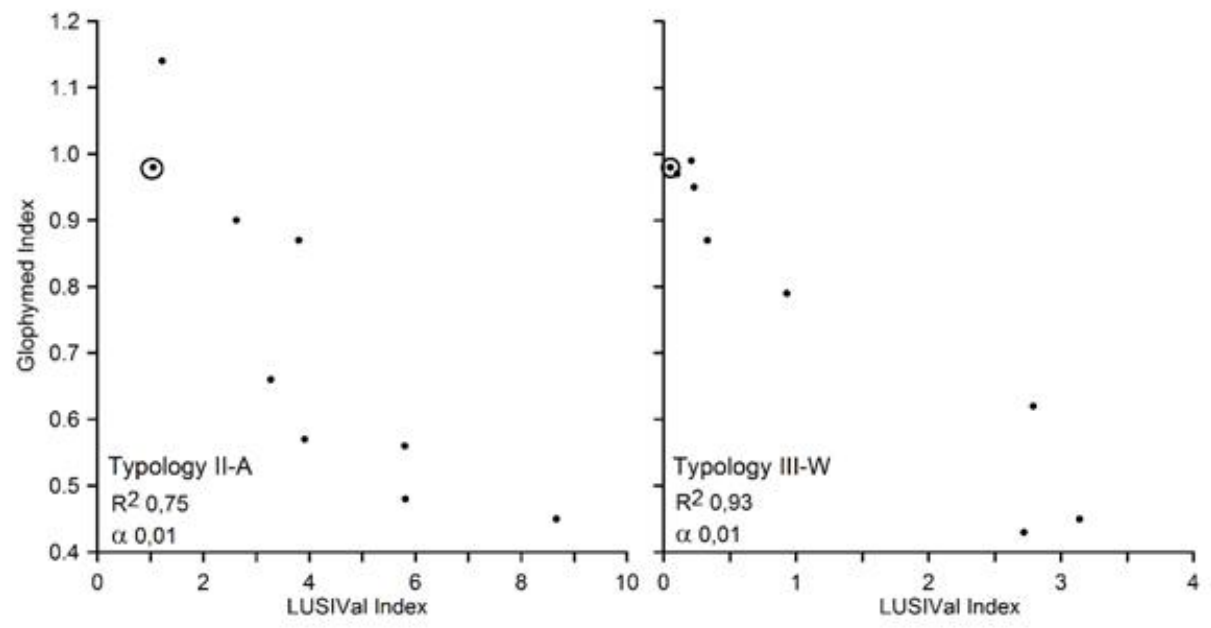

Fig. 2. Global Phytoplankton Index (Glophymed) and Pressure Index LUSIVal correlation for coastal waters. Reference conditions are represented in a circle.

\subsection{Classification of ecological status}

As it has not been developed and IC exercises for the metrics related to phytoplankton (composition, abundance and frequency and intensity of blooms) the boundaries between ecological classes has been achieved by dividing the index into five equidistant intervals.

The global phytoplankton index developed for coastal waters reveals that 9 water bodies are classified as "High" since its values are between 0.8-1. For typologies II-A these water bodies are located at the north of the Comunitat Valenciana where almost all the stretch coastline of this area is at high ecological status (water bodies from 001 to 004). Between them it is found the reference water body defined by the LUSIVal index.

For typology III-W those water bodies at "High" ecological status are located at the north (water bodies from 011 to 015). Between them it is also located the water body defined as a reference. Three water bodies are classified at "Good" status, one of these is type II-A (water body 005) and the rest are of Typology III-W (water bodies 018 and 019). Nevertheless, the Valencia coastline is close to the limit between "Good" and "Moderate" status. This coastal area bears high population density that has been increased over the last decades. Moreover, in the Valencia surrounding area there is an extended industrial activity that added to the harbour zone might be affecting the coastline ecosystem.

It is important to highlight that the boundaries between ecological status must be intercalibrate between MS in the future, and when this occurs the final classification might change since boundary limits between ecological status classes are not lineal.

\section{Conclusions}

The WFD implementation process for coastal waters in Comunitat Valenciana has been an arduous work developed since 2005. A preliminary study based on a holistic approach reveal that coastal water bodies for the Comunitat Valenciana belongs to two typologies II-A and III-W. Each typology is characterized by different geomorphology, littoral transport, dominant winds, rainfall, the area of the fluvial basins, continental inputs, and wet zones. Water bodies 002 (Sierra de Irta) and 012 (Moraira-Peñón de 
Ifach) are those considered as reference conditions since they exhibit the lowest values of an anthropogenic index setting for the Valencian region coastline.

Several variables related to phytoplankton cell density and composition have been selected as the most suitable parameters for describing the ecological status of the coastal ecosystem. The intensity and frequency of blooms episode have been studied for each coastal water body in this five-year period although to define a threshold value for bloom is a challenging task. All these parameters have been addressed by a global index named Glophymed which reflects the response of phytoplankton to environmental conditions better than other indicators currently used based only in chlorophyll a values.

It is worth mentioning that this index defines just one of the biological quality elements listed in the WFD. In order to define the whole ecological status in a water body the remaining elements are to be assessed.

\section{Acknowledgement}

This research work has been supported by the Regional Ministry of the Environment, Water, Urban Planning and Housing.

\section{References}

APHA. 2005. Standard Methods for the Examination of Water and Wastewater, 21th. Washington: American Public Health Association, American Water Works Association, Water Environment Federation.

BEACHMED., 2003. INTERREG III - MEDOCC - BEACHMED. European Project. Strategic management of beach protection for sustainable development of Mediterranean coastal zones. UniversitatPolitècnica de València (Spain). [checked 2012-09-01]: Available in: <http://www.beachmed.eu>.

Brogueira, M.J., Oliveira, MR., Cabeçadas, G., 2007. Phytoplankton community structure defined by key environmental variables in Tagus estuary, Portugal. Mar Environ Res 64, 616-628.

Domingues, R., Barbosa, A., Galvao, H., 2008.Constraints on the use of phytoplankton as a biological quality element within the Water Frame Directive in Portuguese waters. Mar Pollut Bull 56, 1389-1395.

European Commission, 2009. European Commission (Joint Research Centre, Institute for Environment and Sustainability) Alessandro Carletti, Anna-Stiina Heiskanen (Eds.), Water Framework Directive Intercalibration Technical Report. Part 3: Coastal and Transitional Waters, European Commission (2009) Italy. EUR $23838 \mathrm{EN} / 3$

Flo, E., Camp, J., Garcés, E., 2011. Assessment Pressure methodology: Land Uses Simplified Index (LUSI). BQE Phytoplankton. Spain - Catalonia. Work document.

Garmendia, M., Borja, A., Franco, J., Revilla, M., 2012. Phytoplankton composition indicators for the assessment of eutrophication in marine waters: Present state and challenges within the European directives. Mar. Pollut. Bull. http://dx.doi.org/10.1016/j.marpolbul.2012.10.005.

Gotsis-Skretas, O., Horstamann, U., Wiryawan, B., 2000. Cell size structure of phytoplankton communities in relation to physico-chemical parameters and zooplankton in a temperate coastal environment. Arch Fish Mar Res 48, 265-282.

Guidance Document No. 5. Transitional and Coastal Waters - Typology, Reference Conditions and Classification Systems. European Commission. 
GVA. 2002. Catálogo de Zonas Húmedas de la Comunidad Valenciana. http://www.cth.gva.es/areas/espacios/zonas_humedas/zon/memoria2002.pdf.

Hermosilla, Z., 2009. Desarrollo metodológico para la correcta evaluación del estado ecológico de las aguas costeras de la Comunidad Valenciana, en el ámbito de la Directiva Marco del Agua, utilizando la clorofila a como parámetro indicador de la calidad. PhD Tesis, Universidad Politécnica de Valencia, Valencia, España.

Lund, J.W.G., Kipling, C., Le Cren, E.D., 1958. The inverted microscope method of estimating algal numbers and the statistical basis of estimations by counting. Hydrobiologia 11, 143-170.

Moncheva, S., Gotsis-Skretas, O., Pagou, K., Krastev, A., 2001. Phytoplankton blooms in Black Sea and Mediterranean coastal ecosystems subjected to antrophogenic eutrophication: similarities and differences. Estuar Coast Shelf S 53, 281-295.

Pachés, M., Romero, I., Hermosilla, Z., Martínez-Guijarro, R., 2012. PHYMED: An ecological classification system for the Water Framework Directive based on phytoplankton community composition. Ecol Indic 19, 15-23.

Puigserver, M., Ramon, G., Moyà, G., Martinez-Taberner, A., 2002. Planktonic chlorophyll a and eutrophication in two Mediterranean littoral systems (Mallorca Island, Spain). Hydrobiologia 475/476, 493-504.

Serra, J., 2002. Definición de las unidades y subunidades morfodinámicas del litoral del Óvalo Valenciano entre el río Cenia (Castellón) y el cabo de San Antonio (Alicante). Fundación para el fomento de la ingeniería del agua. Valencia (Spain).

Serra, J., Medina, J.R., 1996. Beach monitoring program of Valencia (Spain). 25th International conference on coastal engineering. Book of abstracts. Ed. American Society of Civil Engineering: 590-591.

Simboura, N., Argyrou, M., 2010. An insight into the performance of benthic classification indices tested in Eastern Mediterranean coastal waters. Mar. Pollut. Bull. 60, 701-709.

Sournia, A., 1978. Phytoplankton Manual. Monographs on oceanographic methodology, ed. UNESCO, Paris.

Vargo, G.A., 1978. Using a fluorescence microscope. In: Sournia, A, (Eds.), Phytoplankton manual. Monographs on Oceanography Metodology. UNESCO, pp. 108-112.

Water Frame Directive 2000/60/EC of the European Parliament and of the Council establishing a framework for the Community action in the field of water policy. Official Journal (OJ L 327). Council of European Communities.

Webber, M., Edwards-Myers, E., Campbell, C., Webber, D., 2005. Phytoplankton and zooplankton as indicators of water quality in Discovery Bay, Jamaica. Hydrobiologia 545, 177-193. 